\title{
Suppression of long non-coding RNA H19 inhibits proliferation, cell migration and invasion in human cervical cancer cells
}

\author{
Huawei Xin ${ }^{1}$, Mingzhe $\mathrm{Li}^{2}$, Xiaoling Cheng ${ }^{1}$, Tao Wang ${ }^{2}$, Xiaoliu Liu ${ }^{3 \star}$, Yan \\ Zhang $^{4 *}$ \\ ${ }^{1}$ College of Life Science and Health, Wuhan University of Science and Technology, ${ }^{2}$ Medical School, Hubei Province Key \\ Laboratory of Occupational Hazard Identification and Control, Wuhan University of Science and Technology, Wu Han 430065, \\ ${ }^{4}$ Department of Gynaecology and Obstetrics, Renmin Hospital of Wuhan University, Wuhan 430060, China
}

*For correspondence: Email: IzettaNnna@yahoo.com; Icd5tl@163.com; Tel: +86 2788041911

Sent for review: 23 November 2017

Revised accepted: 19 June 2018

\begin{abstract}
Purpose: To determine the expression profile of IncRNA H19 in different cervical cancers, and to decipher its function in the growth and metastasis of cervical cancer.

Methods: The analysis LncRNA H19 expression was performed using quantitative real time polymerase chain reaction ( $q R T-P C R)$. Cell counting kit 8 (CCK8) assay was used to assess the viability of the cells. The cells were transfected with Si-H19 using Lipofectamine 2000 and the metastasis of cells was determined by cell migration and invasion assay. Immunoblotting was used to evaluate the protein expression.

Results: The IncRNA H19 expression was considerably enhanced in cervical cancer cells, and was about 2.6 to 5.3 times more in cervical cancer cells relative to non-cancer cells. Inhibition of IncRNA caused significant reduction in cervical cancer cell growth in a time-dependent manner. In addition while silencing of IncRNA inhibited the metastasis of HeLa cells. Cell migration and invasion was about $26 \%$ in Si-H19 transfected cervical cancer cells, relative to $65 \%$ in Si-NC cervical HeLa cells. Similarly, cell invasion was $45 \%$ in Si-H19 cervical HeLa cells relative to the negative control (Si-NC). Inhibition of HeLa cell metastasis was also concomitant with decline of metalloproteinases (MMP)-2 and 9 expression.

Conclusion: IncRNA regulates the growth and metastasis of cervical cancer cells. Thus, IncRNA may be an important therapeutic agent for cervical cancer.
\end{abstract}

Keywords: Cervical cancer, IncRNA, Proliferation, Invasion

\begin{abstract}
This is an Open Access article that uses a funding model which does not charge readers or their institutions for access and distributed under the terms of the Creative Commons Attribution License (http://creativecommons.org/licenses/by/4.0) and the Budapest Open Access Initiative (http://www.budapestopenaccessinitiative.org/read), which permit unrestricted use, distribution, and reproduction in any medium, provided the original work is properly credited.

Tropical Journal of Pharmaceutical Research is indexed by Science Citation Index (SciSearch), Scopus, International Pharmaceutical Abstract, Chemical Abstracts, Embase, Index Copernicus, EBSCO, African Index Medicus, JournalSeek, Journal Citation Reports/Science Edition, Directory of Open Access Journals (DOAJ), African Journal Online, Bioline International, Open-J-Gate and Pharmacy Abstracts
\end{abstract}

\section{INTRODUCTION}

Cervical cancer is among the most commonly detected cancers and is ranked as the $3^{\text {rd }}$ most common type of cancers in women worldwide.
Annually, around 0.5 million women are detected with this type of cancer accounting for about $9 \%$ of all the diagnosed cancer cases annually [1]. Although the currently used treatment options such as radical hysterectomy have shown 
encouraging results, cervical cancer is still responsible for about 0.3 million annual deaths in the world. Surgery is the only suitable option for cervical cancers detected at early stage. In addition, radiotherapy has been found to exhibit severe adverse effects on the health of the patients [2]. Therefore, it is very important to either explore new drugs or to identify novel targets for the management of cervical cancer.

Long non-coding RNAs (IncRNAs) form a large group of RNA molecules which are more than 200 nucleotides long. These RNA molecules do not code for proteins, and they lack a complete open reading frame [3]. Studies carried out over the last few years suggest that IncRNAs play pivotal functions in a number of biological processes, including regulation of gene expression via DNA methylation [4].The IncRNAs have also been found have an involvement in cancer progression and metastasis [5]. The expression of several IncRNAs is deregulated. Therefore, they are considered as potential therapeutic agents [6]. As per earlier investigations, IncRNA $\mathrm{H} 19$ is upregulated in several cancers such as breast and bladder cancers [7]. The expression of H19 decreases in human cells from birth but its expression gets upregulated in cancer cells, and has therefore been implicated in the development of cancers $[8,9]$.

In this study, the expression of IncRNA H19 was investigated in different cervical cancer cell lines. Its influence on the growth and metastasis was also investigated.

\section{EXPERIMENTAL}

\section{Cell lines and culture conditions}

Human cervical cancer (HeLa, CaSki, MARQ, C33A, C4-1 and SW756) and non-cancerous (HNCF-PI 15) cells were obtained from Type Culture Collection of Chinese Academy of Sciences, Shanghai, China and were cultured in RPMI 1640 complete media containing 10\% FBS and antibiotics (100 U/mL penicillin and 100 $\mathrm{U} / \mathrm{mL}$ streptomycin), at $37^{\circ} \mathrm{C}$ in a humidified chamber.

\section{Assay of IncRNA H19 by RT-PCR}

Total RNA was isolated from the cervical cancer cells with the help of RNeasy RNA Isolation Kit following the guidelines of the manufacturer and cDNA was synthesized from it by employing RevertAid cDNA Synthesis Kit (Fermentas). The cDNA samples were subjected to qRT-PCR analysis using SYBR Green Master Mix
(Fermentas). For determination of differences in the expressions of IncRNA $\mathrm{H} 19$ in different samples, the ${ }^{\Delta \Delta-} \mathrm{CT}$ method was used. Actin served as internal control.

\section{Suppression of IncRNA H-19}

H19-siRNAs (Si-H19) and the negative control siRNA (Si-NC) were obtained from Genepharm (Shanghai, China), and were transfected into cervical cancer using Lipofectamine 2000 reagent (Invitrogen).

\section{Investigation cell proliferation by CCK8 assay}

In order to determine the rate of proliferation rate of HeLa cells, CCK-8 assay was carried out. The HeLa cells (both Si-NC and $\mathrm{Si}-\mathrm{H} 19$ ) were collected at varied time intervals after transfection, and cell viability was assessed using Cell Numbering Kit-18 (Dojondo, Japan) as per the guidelines of the kit manufacturer.

\section{Cell migration assay}

The migration of HeLa (Si-NC and Si-H19) cells was determined with wound healing assay. The cells were grown till confluence and a scratch was made with a scratching device. The cells were then incubated for $48 \mathrm{~h}$ again, and the wound healing capacity of Si-NC and Si-H19 transfected cells was evaluated by comparing the widths of the wounds.

\section{Matrigel invasion assay}

Invasion was evaluated with the help of Matrigelß-coated invasion chambers. The Si-NC and $\mathrm{Si}-\mathrm{H} 19 \mathrm{HeLa}$ cells that reached the lower surface of the membrane were subjected to staining with crystal violet $(\mathrm{CV})$, and the images of CV-stained cells were taken. The crystal violet complexes formed were dissolved in $10 \%$ acetic acid and the cell invasion was determined by measuring the absorbances of the resultant solutions at $600 \mathrm{~nm}$ in a spectrophotometer.

\section{Western blotting analysis}

Si-NC and Si-H19 transfected HeLa cervical cancels were collected and treated with lysis buffer. The extracts were boiled for $10 \mathrm{~min}$ in the presence of loading buffer, followed by separation of cell extracts using $15 \%$ SDSPAGE gel. The samples were then put onto polyvinylidene fluoride membranes and subjected to blocking with skim milk (5\%). Membrane incubation with primary antibodies was performed overnight at $4^{\circ} \mathrm{C}$ and subsequently incubated with horseradish 
peroxidase-linked biotinylated secondary antibodies at 1:1,000 dilution for $2 \mathrm{~h}$. The membranes were then subjected to washing with PBS and the immune-reactive bands were visualized using ECL-PLUSKit. The development of the immune complexes was carried out using an ECL detection kit according to the manual protocol. The bands were analyzed with Ge1GDoc 2000 imaging system.

\section{Statistical analysis}

Each test was carried out thrice and the values are presented as mean $\pm S D$. Student's $t$-test was employed for statistical analysis using GraphPad prim 6 software.

\section{RESULTS}

\section{IncRNA H19 upregulated in cervical cancer cell lines}

The qRT-PCR results showed that IncRNA H19 expression was enhanced in cervical cancer cells as against the non-cancerous cell line HNC-PI 15. The expression of IncRNA H19 was about 2.6 to 5.3 times more in cervical cancer cells as against the non-cancer cells. In addition, the expression of IncRNA H19 was found to be highest MARQ and comparatively lower in CaSki cells. Out of these all the cell lines, HeLa cervical cancer cells were selected for further experimentation (Figure 1).

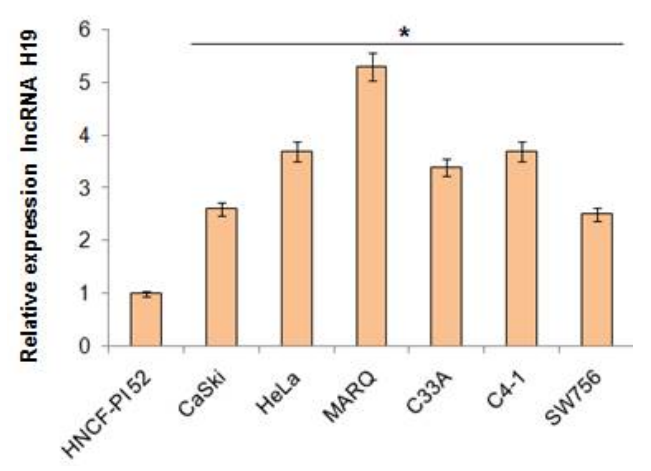

Figure 1: The IncRNA H19 expression in different cervical cancer lines as depicted by qRT-PCR analysis. The values are mean $\pm \mathrm{SD}(\mathrm{n}=3)$ and $\left({ }^{*} p<\right.$ 0.01 vs normal cells used as control)

\section{Silencing of IncRNA H19 inhibits cell proliferation}

The expression of IncRNA H19 was considerably suppressed in Si-H19 cervical HeLa cancer cells (Figure 2). Furthermore, it was found that the silencing of IncRNA H19 caused significant suppression of growth of HeLa cells as evident from the CCK8 proliferation assay (Figure 3 ).

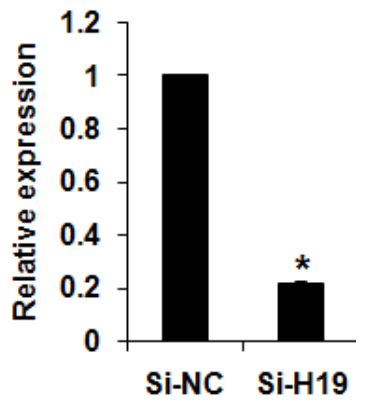

Figure 2: Expression of IncRNA H19 in Si-NC and siH19 transfected cervical cancer lines as depicted by qRT-PCR analysis. Values are mean $\pm \mathrm{SD}(\mathrm{n}=3)\left({ }^{*} p\right.$ $<0.01$, Si-H9 Vs Si-NC)

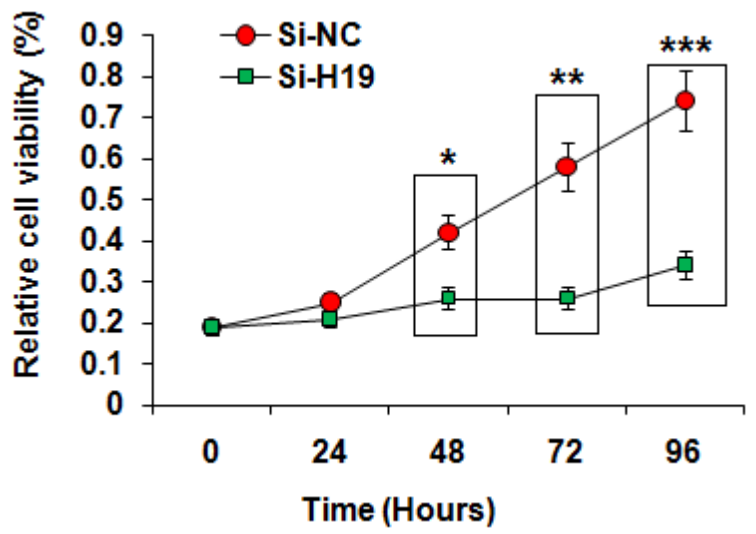

Figure 3: Relative cell viability of $\mathrm{Si}-\mathrm{NC}$ and $\mathrm{si}-\mathrm{H} 19$ transfected cervical cancer lines as revealed by CCK8 assay. Values are mean $\pm \mathrm{SD}\left(\mathrm{n}=3,{ }^{*} p<0.01,{ }^{\star *} p<\right.$ $0.001,{ }^{* * *} p<0.0001 ; \mathrm{Si}-\mathrm{H} 9$ vs $\left.\mathrm{Si}-\mathrm{NC}\right)$

\section{Silencing of IncRNA H19 inhibits cell migration}

Further the effect of IncRNA H19 silencing on migration of the HeLa cells was also assessed. The results revealed that the cell migration of $\mathrm{Si}$ H19 HeLa cells was significantly inhibited when compared to the Si-NC cervical HeLa cancer cells used as negative control (Figure $4 \mathrm{~A}$ ). The percent cell migration was found to be around 26 $\%$ in Si-H19 transfected cervical cancer cells as compared to $65 \%$ the Si-NC cervical HeLa cancer cells. Moreover, the inhibition of cell migration was concomitant with suppression of Metalloproteinases MMP-9 and MMP-2 as shown in the western blots (Figure $4 \mathrm{~B}$ ).

\section{Silencing of IncRNA H19 inhibits cell invasion}

The results of Matrigel assay showed that the cell invasion of $\mathrm{Si}-\mathrm{H} 19$ cancer cells was considerably suppressed as against the negative control (Si-NC). The cell invasion was found to be $45 \%$ in Si-H19 cervical HeLa cancer cells relative to the negative control (Si-NC) (Figure 5). 
A

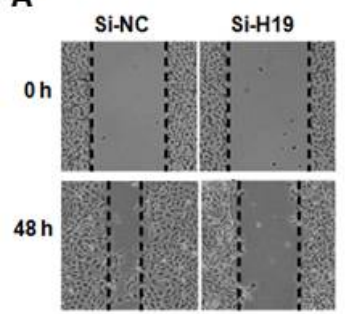

B

Figure 4: (A) Migration of negative control (NC) and si-H19 transfected cervical cancer lines as depicted by wound healing migration assay. (B) Protein expression of MMP-2 and MMP-9 Si-NC and si-H19 transfected cervical cancer cells. Values are mean $\pm \mathrm{SD}\left(\mathrm{n}=3,{ }^{*} p\right.$ $<0.01$; $\mathrm{Si}-\mathrm{H} 9 \mathrm{Vs} \mathrm{Si}-\mathrm{NC}$ )
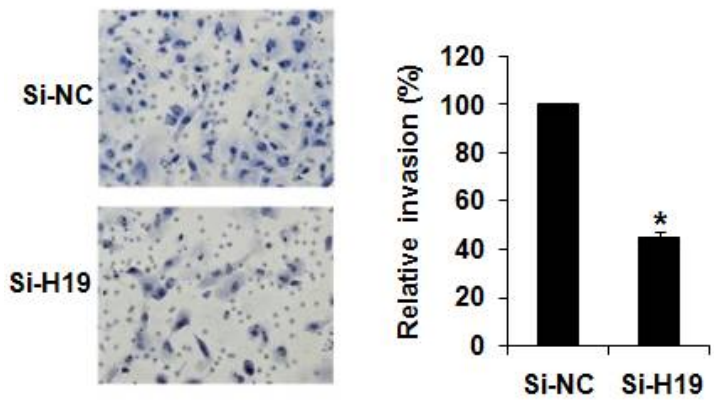

Figure 5: Cell invasion of Si-NC and si-H19 transfected cervical cancer lines as depicted by matrigel assay. Values are mean $\pm \mathrm{SD}\left(\mathrm{n}=3,{ }^{*} p<\right.$ 0.01; Si-H19 Vs Si-NC)

\section{DISCUSSION}

Cervical cancer is commonly found women and causes considerable mortality and morbidity. The current treatments are inefficient, have side effects and are very costly [1]. In addition, the availability of chemotherapeutic drugs for cervical cancer is also limited [10]. Therefore, need of the hour is to identify novel and prospective therapeutic targets for the treatment of cervical cancer. Long non-coding RNAs have emerged as important RNA molecules that have been reported to be implicated in large number of biological processes [11].Several of the IncRNAs have been reported to be deregulated in cancers and have therefore been considered as key therapeutic targets for cancer treatments [12].

Herein the role of IncRNA H19 in the cervical cancers was investigated. Previous studies have shown that the transcription of IncRNA H19 is deregulated in different types of cancers. Keeping this in view, the expression of IncRNA

$\mathrm{H} 19$ in six cervical and one normal cell lines was examined. It was found that the expression of IncRNA was 5.6 times more in cervical cancer cells relative to the no-cancerous cells. Similar observations were found in breast cancer cells wherein IncRNAH19 was also upregulated [13]. The qRT-PCR analysis gave first hint about the prospective of IncRNA H19 as therapeutic agent for treating cervical cancer. To decipher the function of IncRNA H19 in HeLa cell proliferation, IncRNA H19 was silenced by RNA interface in HeLa cells. It was found that the silencing of IncRNA H19 declined the viability of HeLa cells in a time dependently. These results are in accordance with previous studies which have reported that several of the IncRNAs inhibit cancer cell proliferation [14]. The mortality of cancer cells is an important factor for their metastasis of the cancers. Hence, inhibiting the cell migration and invasion are considered very imperative for development of treatment strategies for different types of cancers [15]. Therefore, impact of IncRNA H19 silencing on the metastasis cancer cells were also investigated.

The results of wound healing revealed that silencing of IncRNA caused significant halt in HeLa cervical cancer cell migration. Similar results were obtained in Matrigel invasion assay wherein the silencing of IncRNA caused a significant reduction in cell invasion. Similar results have been reported previously wherein the inhibition of IncRNAs halted the invasion of HeLa cells [16]. Furthermore, the immunoblotting revealed that suppression of metastasis was concomitant with suppression of MMP-2 and MMP which are considered important for metastasis of the cancer cells [17]. To sum up, these results indicate that IncRNA H19 may prove to beneficial for treating cervical cancer.

\section{CONCLUSION}

The results obtained in the study indicate that IncRNA H19 is highly enhanced in cervical cancer cells. Silencing of IncRNA causes decline in cervical cancer cell proliferation and metastasis. Thus, IncRNA H19 may prove to be a potent target for drugs in cervical cancer therapy.

\section{DECLARATIONS}

\section{Acknowledgement}

The authors acknowledge the Department of Gynaecology and Obstetrics, Renaming Hospital of Wuhan University, Wuhan 430060, China for providing the required facilities. 


\section{Conflict of interest}

No conflict of interest is associated with this work.

\section{Contribution of authors}

The authors declare that this work was done by the authors named in this article and all liabilities pertaining to claims relating to the content of this article will be borne by them. Huawei Xin and Mingzhe Li performed most experiments and contributed to this work equally under supervision of Xiaoliu Liu and Yan Zhang. Xiaoling Cheng, Tao Wang helped.

\section{REFERENCES}

1. Muñoz $N$, Bosch $F X$, de Sanjosé $S$, Herrero $R$, Castellsagué $X$, Shah KV, Snijders PJ, Meijer CJ. Epidemiologic classification of human papillomavirus types associated with cervical cancer. New Eng J Med 2003; 348: 518-527.

2. Franco EL, Duarte-Franco E, Ferenczy A. Cervical cancer: epidemiology, prevention and the role of human papillomavirus infection. Canadian Med Ass J 2001; 164: 1017-1025.

3. Yang G, Lu X, Yuan L. LncRNA: a link between RNA and cancer. Biochimica et Biophysica Acta (BBA)-Gene Regulatory Mechanisms 2014; 1839(11): 1097-109.

4. Augoff K, McCue B, Plow EF, Sossey-Alaoui K. miR-31 and its host gene IncRNA LOC554202 are regulated by promoter hypermethylation in triple-negative breast cancer. Mol Cancer 2012; 11: 5-9.

5. Qiu MT, Hu JW, Yin R, Xu L. Long noncoding RNA: an emerging paradigm of cancer research. Tumor Biol 2013; 34: 613-620.

6. Yang Y, Li H, Hou S, Hu B, Liu J, Wang J. The noncoding RNA expression profile and the effect of IncRNA AK126698 on cisplatin resistance in non-small-cell lung cancer cell. PloS one 2013; 8: e65309.

7. Yang $F$, Bi J, Xue $X$, Zheng L, Zhi K, Hua J, Fang G. Up-regulated long non-coding RNA H19 contributes to proliferation of gastric cancer cells. FEBS J 2012; 279): 3159-3165.

8. Vennin C, Spruyt N, Dahmani F, Julien S, Bertucci $F$, Finetti $P$, Chassat $T$, Bourette $R P$, Le Bourhis $X$, Adriaenssens E. $H 19$ non coding RNA-derived miR-675 enhances tumorigenesis and metastasis of breast cancer cells by downregulating $c-C b l$ and Cbl-b. Oncotarget 2015; 6: 29209-29213.

9. Zamore PD, Tuschl T, Sharp PA, Bartel DP. RNAi: double-stranded RNA directs the ATP-dependent cleavage of mRNA at 21 to 23 nucleotide intervals. Cell 2000; 101: 25-33.

10. Lovy A, Knowles B, Labbe R, Nolan L. Activity of edible mushrooms against the growth of human T4 leukemic cancer cells, HeLa cervical cancer cells, and Plasmodium falciparum. J Herbs, Spices Med Plants 2000; 6:49-57.

11. Huarte $M$. The emerging role of IncRNAs in cancer. Nature medicine 2015; 21(11): 1253-61.

12. Gibb EA, Vucic EA, Enfield KS, Stewart GL, Lonergan KM, Kennett JY, Becker-Santos DD, MacAulay CE, Lam $S$, Brown CJ, et al., Human cancer long non-coding RNA transcriptomes. PloS one 2011; 6: e25915.

13. Berteaux N, Lottin S, Monté D, Pinte S, Quatannens B, Coll J, Hondermarck $H$, Curgy JJ, Dugimont $T$, Adriaenssens E. H19 mRNA-like noncoding RNA promotes breast cancer cell proliferation through positive control by E2F1. J Biol Chem 2005; 280: 29625 29636.

14. Ying $L$, Chen $Q$, Wang $Y$, Zhou Z, Huang $Y$, Qiu $F$. Upregulated MALAT-1 contributes to bladder cancer cell migration by inducing epithelial-to-mesenchymal transition. Mol Biosyst 2012; 8: 2289-2294.

15. Björklund M, Koivunen E. Gelatinase-mediated migration and invasion of cancer cells. Biochim Biophys Acta 2005; 1755: 37-69.

16. Yuan JH, Yang F, Wang F, Ma JZ, Guo YJ, Tao QF, Liu $F$, Pan W, Wang TT, Zhou CC, et al., A long noncoding RNA activated by TGF- $\beta$ promotes the invasionmetastasis cascade in hepatocellular carcinoma. Cancer Cell 2014; 25: 666-6681.

17. Salo T, Mäkelä $M$, Kylmäniemi $M$, Autio-Harmainen $H$, Larjava $H$. Expression of matrix metalloproteinase-2 and-9 during early human wound healing. Lab investing: J Technical Meth Pathol 1994; 70: 176-82. 